\title{
From Po-li to Rajah Brooke: Culture, Power and the Contest for Sarawak
}

\author{
John Henry Walker \\ International and Political Studies,University of New South Wales \\ Canberra, Australia
}

*Corresponding author

Email address: j.walker@adfa.edu.au.

\begin{abstract}
This article explores Sarawak's remoter past from the emergence of an early Indianised state at Santubong until the accession as Rajah of Sarawak of James Brooke. Through an analysis of Sarawak Malay oral histories, the Negara-Kertagama, Selsilah Raja Raja Sambas and the Selsilah Raja RajaBerunai, the article confirms and extends IbLarsens's findings, that extensive periods of Sambas's rule over Sarawak has been overlooked by successive scholars. The article also explores the ways in which Malay oral and traditional histories can be used in western historiographic traditions to illuminate the remoter past.
\end{abstract}

Keywords:Indianisation, Sarawak, Sambas, Brunei, DatuMerpati, Sultan Tengah

Prior to the expansion of its meaning in the $19^{\text {th }}$ and early $20^{\text {th }}$ centuries, the term 'Sarawak' referred to a negri(country) which encompassed the Sarawak and Lundu River basins, and the coast and adjacent islands between the mouths of the Sarawak and Lundu Rivers, an area known in the scholarly literature as 'Sarawak Proper', to distinguish it from the more expansive Sarawak which we know today. ${ }^{1}$

AlthoughSarawak achieved its present boundaries only with the transfer of Lawas from the British North Borneo Company in January 1905, ${ }^{2}$ it has a long and contested, if intermittently documented, history.

In 2012, Ib Larsen suggested that large parts of present day Sarawak had been ruled for significant periods of time by Sambas rather than by Brunei. Focussing, in

1 All references in this paper to Sarawak, except where indicated, refer to Sarawak Proper.

2 S. Baring-Gould and C. A. Bampfylde, A History of Sarawak under its Two White Rajahs, 1839-1908. London: Henry Sotheran, 1909. p. 365. 
particular, on narratives concerning Raja Tengah, and on English sources from the early $19^{\text {th }}$ Century, Larsen convincingly demonstrated that Sarawak was ruled by the Sambas dynasty for much of the $17^{\text {th }}$ century, and during the early $19^{\text {th }}$ century. ${ }^{3}$ This essay seeks to confirm and to extend Larsen's findings, and to place them in a longerterm context, in the process illuminating little known aspects of the enduring contest for Sarawak before Brooke rule.It does so through references to the NegaraKertagama, narratives concerning Datu Merpati and oral traditions obtained from elderly abang-abang from Kuching, information to which Larsen did not have access.

Beyond the Chinese language sources, ${ }^{4}$ the most important of the earliest known references to Sarawak, both to Sarawak Proper and to a number of places nowencompassed in Sarawak's present borders, are to be found in the mid-14 ${ }^{\text {th }}$ Century Court text from Majapahit, the Negara-Kertagama, Chapter III of which purports to list the dependencies of Majapahit.Someof the placenames listed in Borneo - Kapuhas, Sambas, Katingan and Kuta Waringin, for example -are familiar to us. Ofmoreinterest, however,are the listingof Kuta-Lingga, Sedu, Buruneng, Kalka, Sawaku and Malano.Theodore Pigeaud identified Kuta-Lingga with Lingga, Sedu with Sadong, Buruneng with Brunei, Kalka with Kalakka and Malano with the Melanau territories, "east of the mouth the river Rejang in Serawak". ${ }^{5}$ Although Pigeaud identified Sawaku with Pulau Sebuku, ${ }^{6}$ itcan,more plausably,be identified with Sarawak. If this latter suggestionwereto be accepted, Rakawi Prapanca listed, as one travels west to east, the negris of Sarawak, Sadong, Lingga, Kalakka and Melanau.

3 Ib Larsen, "The First Sultan of Sarawak and his Links to Brunei and the Sambas Dynastty, 1599-1826: A Little-known Pre-Brooke History", Journal of the Malaysian Branch of the Royal Asiatic Society, 85:2, 2012. pp. 1-16.

W. P Groeneveldt, Notes on the Malay Archipelago and Malacca compiled from Chinese sources. Jakarta: C.V. Bhratara. Rpt. 1960. See also, however, Johannes L. Kurz, "Pre-modern Chinese Sources in the National History of Brunei: The Case of Poli”, Bijdragen tot de Taal-, Land- en Volkenkunde 169 (2013), pp. 213-243.

5 Theodore G. Th. Pigeaud, Java in the $14^{\text {th }}$ Century: A Study in Cultural History - The Negara-Kertagama by Rakawi Prapanca of Majapahit, 1365 A.D. The Hague: Martinus Nijhoff, 1960. See vol. III, pp. 16-17. Bizarrely, A. H. Hill wrote, "In the list of countries subject to Majapahit given in the Negarakretagama [sic]... there is no mention of any part of the island ob Borneo". A. H. Hill, "Manggeng and Datu Merpati", Journal of the Malayan Branch of the Royal Asiatic Society, 28:1, 1955. pp. 148-158 at p. 155. 
As Tom Harrisson noted, it "is probable that West Borneo only came into full Majapahit influence towards the middle of the $14^{\text {th }}$ century; by the end of that century the empire was crumbling". ${ }^{7}$ This late association of Sarawak with Majapahitwould explain why the Negara-Kertagama makes no mention of the $10^{\text {th }}$ to $13^{\text {th }}$ century state of Po-ni, centred on Santubong (see below). Although Harrisson speculated that Brunei "had become the northern centre of administration" in the Majapahit Empire, ${ }^{8} \mathrm{I}$ have found no evidence to suggest that Bruneihad, in the mid- $14^{\text {th }}$ Century, achieved any predominence over its neighbours.

\section{Indianisation}

Majapahit has long been suggested by scholars as being the source of the Hindu influences observed in the cultures of some Sarawak peoples. Baring-Gould and Bampfylde observed of the Land Dyaks (Bidayuh):

The remains found among them of Hinduism, such as a stone-shaped bull, and other carved monumental stones, and the name of their deity, Jewata, as also the refusal among them to touch the flesh of cattle and deer, and the cremation of their dead, show that they must have been brought into intimate contact with the Hindus, probably at the time when the Hindu-Javanese Empire of Majapahit extended to Borneo. 9

H. R. Hughes-Hallet, similarly, considered that "Hindu influence emanated from the empire of Majapahit in Java". ${ }^{10}$

Scholarsshould exercise caution, however, in assuming that the Indianisationofcultures in Sarawak derived, necessarily,from Sarawak'srelationship withMajapahit. The Indianisationof Sarawak cultures could have occurred independently of Majapahit and, indeed, well before that empire's existence. Archaeological remains discovered at Kutaiin east Kalimantan, for example,suggest that it was the site of an Indianised state dating from the fifth century. ${ }^{11}$

Of more importance than Kutai in Indianisation in northwest Borneo is James Ongkili's identification of a seventh century state in northwest Borneo, which was

7 Tom Harrisson, "Gold \& Indian Influences in West Borneo", Journal of the Malayan Branch of the Royal Asiatic Society. 22: 4 (150), 1949, pp. 33-110 at p. 103.

8 Ibid.

9 S. Baring-Gould and C. A. Bampfylde, op. cit., p. 21.

10 H. R. Hughes-Hallett, "A Sketch of the History of Brunei”, Journal of the Malayan Branch of the Royal Asiatic Society, XVIII:2, 1940. pp. 24-42 at p. 24.

11 Roland Braddell, "A Note on Sambas and Sarawak", Journal of the Malayan Branch of the Royal Asiatic Society, 22:4 (150), 1949. pp. 1-15 at p. 3. 
known as Vijayapura. The fact thatVijayapura is a Sanskrit term unequivocally suggests that it was Indianisedcenturies before the emergence of Majapahit. Its name, moreover, strongly suggests that it might have been part of the thassalocracy of Srivijaya, of which it was a contemporary. ${ }^{12}$ Although the locations and identifications of early states in northwest Borneo are contentious, and probably beyond definitive conclusions, ${ }^{13}$ Edward Banks quoted J. L. Moensto suggestthat Vijayapurawas located in the Rajang River delta. ${ }^{14}$

Vijayapura was contemporaneous with another state recorded in the Chinese sources, P'o-li, which some scholars have located on Borneo's northwest coast, ${ }^{15}$ and about which more detail is known. P'o-li is recorded as sending embassies to China in 518, 523, 616 and 630 CE. An Indianised state, P'o-li was Buddhist and its dynasty's name was Kaundinya, as was, famously, that of Funan. ${ }^{16}$ One of the Chinese sources records of P'o-li, "In this country they have a kind of fire-pearls, of which some are as large as a hen's egg; they are round and white, and shed a lustre to a distance of several feet; if you let the sun shine through them on tinder it takes fire immediately". 17

The next advanced state on Borneo's northwest coast was Po-ni, which emerged in the Chinese written sources during the late $10^{\text {th }}$ century, ${ }^{18}$ following the disappearance ofP'o-li from the Chinese sources.If Roland Braddell was correct in

12 See James P. Ongkili, "Pre-Western Brunei, Sarawak and Sabah", Sarawak Museum Journal, 20 (40-44), Jan-Dec, 1972, pp. 1-20 at pp. 2-4 and Robert Nicholl, "Some Problems of Brunei Chronology", Journal of Southeast Asian Studies, 20 (2), September, 1989, pp. 175-195 at pp. 178 \& 193.

13 For a thorough and measured analysis of the available data see Stephen Charles Druce, "The 'birth' of Brunei: Early polities on the northwest coast of Borneo and the origins of Brunei”, in Ooi Keat Gin (ed.), Brunei - History, Islam, Society and Contemporary Issues. London and New York: Routledge, 2016. pp. 21-44.

14 J. L. Moens, quoted by E. Banks, "Ancient Times in Borneo", Journal of the Malayan Branch of the Royal Asiatic Society, 20:2, 1947, pp. 26-34 at p. 31.

15 Stephen Charles Druce, op. cit., pp. 24. But see also Johannes L. Kurz, op. cit.

16 Roland Braddell, op. cit., p. 6. For a discussion of 'Kaundinya' in southeast Asian history see A. O. Richardson, The Austronesian Impulse: 'Great Tradition' Change in Precolonial Southeast Asia. Honours Thesis, University of New South Wales, Canberra, 2016. pp. 34-36.

17 Ibid., p. 8.

18 Jan Wisseman Christie, "On Po-ni: The Santubong Sites of Sarawak", Sarawak Museum Journal, XXXIV, 55, December 1985, pp. 77-89 at p. 79. 
arguing that the two names are philologically the same, ${ }^{19}$ Po-nican be considered to be the later name for P'o-li.

Jan Wisseman Christie was confident that Po-ni was centred on Santubong, at the mouth of the Sarawak River. Po-ni was recorded as exporting camphor, beeswax, laka wood, civet and tortoiseshell. ${ }^{20}$ From these exports, we can deduce that the rulers of Po-ni enjoyed extensive trading or tributary relations with up-river tribal groups skilled in the collection of forest products. Its export of tortoiseshell, similarly, suggests that the Po-ni elite had similarly strong relations with Orang Laut, Bajau or similar groups of sea nomads, skilled in exploiting the resources of the maritime littoral. ${ }^{21}$ Suggesting that Po-ni was a predecessor state to, rather than an earlier name for, Brunei, Christie argued that, while centred on Santubong, "it apparently drew on feeder ports strung out along much of the north coast". Fourteen of these ports were identified in the Chinese sources. ${ }^{22}$

Po-ni was also the site of a significant iron smelting industry. Whereas Harrisson and O'Connor argued that it was a large-scale, export focused industry, ${ }^{23}$ Christie has demonstratedconvincingly that they mistook the sources of iron as large amounts to slag by-product. Rather than a large scale export industry, Christie proposed that the Santubong was the site of a smaller, local industry, producing iron to trade with interior groups of forest-product collectors. ${ }^{24}$ The population of Santubong peaked in the late $12^{\text {th }}$ and $13^{\text {th }}$ centuries, after which decline set in. Santubong was virtually deserted by the $14^{\text {th }}$ Century. ${ }^{25}$

\section{DatuMerpati}

Although, therefore, it is likely that the cultures of the peoples of Sarawak had been

19 Roland Braddell, op. cit., pp. 5, 8.

20 Ibid., p. 80.

21 For an alysis of the importance of various sea nomad groups in gathering maritime products for land-based polities see James Haw, Sea Nomads: States and State Resistance in Maritime Southeast Asia, Honours Thesis, University of New South Wales, Canberra, 2013.

22 Jan Wisseman Christie, op. cit., pp. 80-81. For a discussion of Po-li and Po-ni see Stephen Charles Druce, op. cit., pp. 24-25.

23 Tom Harrisson and Stanley J. O'Connor, Excavations of the Pre-historic Iron Industry in West Borneo. Cornell Southeast Asian Program, Data Paper No. 72, 1969.

24 Jan Wisseman Christie, op. cit., pp. 82-83.

25 Ibid., p. 82. 
partially Indianised prior to the emergence of Majapahit, the historical traditions of the Sarawak River Malays unequivocally claim Javanese origins for the abang-abang families of Kuching, tracing their descent to the famed DatuMerpati. ${ }^{26}$

The earliest transcription of the Merpati stories known to this authorwas published in 1909 by Harold H. Everett and John Hewitt, who recorded that it had been written down some 40 years earlier(about 1870) by a "Malay scribe". ${ }^{27}$ In this version, DatuMerpati's origins are not of this world.

Many years ago there came down from Heaven an illustrious person called Rajah Paribata Sri. Deciding to stay on earth he took to himself a wife and became the father of three children - by name, RadinDipati, RadinUrei Sri and RadinGosti. ${ }^{28}$

The heavenly origins attributed to DatuMerpatiin this version are significant, because such origins are onlyattributed to the progenitors of royal dynasties. Thus the 1870 recensionalso accords the royal Javanese titles of radin and gusti to the three childrenand, uniquely among the various versions of the Merpati story, claims that, even during DatuMerpati's lifetime, his son, ChipangMerapati (MerpatiJerpang) "assumes the rank of Rajah at BatuBoiak (near Santubong)" wherehe "lived and ruled ... for many years, and we are told that his people included as well as Malaysmany immigrants from China and from India”. ${ }^{29}$

In contrast to Everatt and Hewitt's version of the Merpati story, versions collected byTom Harrissonand Mohammed YusofShibliboth hadDatuMerpati asbeing the patrilineal grandson of Raja Jawa. ${ }^{30}$ Harrisson published another two versions of the DatuMerpati stories, one collected from Serian, a mixed Malay/Bidayuh area,

26 Abang (lit. older brother) is a title used by elite Malays from the Sarawak, Sadong, Seribas and Skrang Rivers in Sarawak, and also by some of the ruling families of the Kapuas River in west Kalimantan. It is inherited patrilineally. Daughters of abangs are dayangs.

27 Harold H. Everett and John Hewitt, "A History of Santubong, an Island off the Coast of Sarawak", Journal of the Straits Branch of the Royal Asiatic Society, No. 52, 1909, pp. $1-30$ at p. 18.

28 Ibid., p. 13.

29 Ibid., p. 17.

30 Tom Harrsson, "Gold \& Indian Influences in West Borneo", p. 96. Mohd. Yusuf Shibli, "The Descent of Some Kuching Malays", Sarawak Museum Journal, V (2), 1950, pp. 262-264 at p. 262. 
which Harrisson characterised as aBidayuh version, ${ }^{31}$ and another, Malay, version, collected by A.K. MericanSalleh. ${ }^{32}$ Neither of Harrisson's versions refer to DatuMerpati or his son, MerpatiJerpang, becoming rulers.

The grandson,therefore, either of a being who descended fromHeaven or of the Rajah Jawa, DatuMerpatitook refuge inJohor, where he married the daughter of the ruler of Johor, before settling, first,near Pontianak, then at TanjongDatu and, subsequently, at Santubong. Both DatuMerpati and his son, MerpatiJerpang, are remembered as collecting taxes from the local people. ${ }^{33}$ Although, in the salsilah(descent chart, pedigree or family tree) of DatuTumanggongAbangKipali, which Harrisson published, DatuMerpati is also remembered as DatuMerpatiRadenGusti, ${ }^{34}$ this recension makes no claims to the family exercising sovereign powers.

DatuMerpati, his son, MerpatiJerpang, grandson, PatehMengada and his greatgrandson, Pateh Malang, all bore the pati/pateh title. In contrast, the descendants of Pateh Malang bore the Malay-language title,patinggi. ${ }^{35}$ Although it would be unwise to be dogmatic on the issue, it seems likely that the use of pati/pateh by the first four generations of the family to live in Sarawak, coupled with DatuMerpati's reported descent from Raja Jawa, suggests that they considered themselves to be officials of polity based in Java.

An old man in 1970, AbangKipaliwas 16 generations removed from DatuMerpati. ${ }^{36}$ In attempting to date events in polygamous societies by using

31 Tom Harrisson, The Malays of Southwest Sarawak before Malaysia: A Socioecological Survey. London: Macmillan, 1970. pp. 124-126.

32 Ibid., pp. 127-130. Harrisson also published another version of the story in his "Gold \& Indian Influences in West Borneo", pp. 96-98. A. H. Hill published a version in 1955. A. H. Hill, op. cit. pp. pp. 148-158. See also Haji Mohammad Tahir bin Abdul Ghani, Hikayat Datu Merpati, Kuala Lumpur: Dewan Bahasa dan Pustaka, 1989.

33 Harold H. Everett and John Hewitt, op. cit., p. 15.

34 Tom Harrisson, The Malays of Southwest Sarawak. p. 123. As already noted, raden and gusti denote royal descent, whle pati carries administrative connotations. John Crawford also considered the title, adipati, to be "in Java the title of the highest nobility". John Crawford, A Descriptive Dictionary of the Indian Islands and Adjacent Countries. London: Bradbury and Evans, 1856. p. 62. 
genealogical information, each generation should be allowed 30-35 years. ${ }^{37}$ Following this assumption, DatuMerpati was active in Sarawak somewhere between 1410 and 1490. These dates, coupled with the use of the Majapahit title, pati/pateh, suggestthat the four patis/patehswere, or claimed to be, the local representatives of Majapahit.

The abandonment by the descendants of Pateh Malang of the pati/pateh title, in favour of the Malay-languagepatinggi,probably denotes the collapse of Majapahit power, or the exclusion of its power bya Malay-speaking rival. These were probably long, drawn out processes, which created a period of ambiguityabout control and power. Perhaps it is this ambiguity that explains why the SalsilahAbangKipali describes DatuMerpati's grandson, PatehMengada, as being also the first "Malay Patinggi". ${ }^{38}$ It was only after the death of PatehMengada's son, PatehMalang, that the family gave up, altogether, the use of the pati/patehtitle. ${ }^{39}$

\section{Johor/Sambas}

The Selsilah Raja Raja Bruneirecords that, following the collapse of Majapahitrule,by the end of the 15th century, control of the fivenegrisof Sarawak, Samarahan, Sadong, Saribas and Kalakkapassed to Johor, whose ruler,subsequently, is recorded as transferringsovereignty over them to the first Sultan of Brunei, when the latter converted to Islam and married the Johor ruler's daughter. 40

The central role of Johor in both the Merpati stories and the Brunei Selsilah is problematic, however. First, the events under discussion almost certainly occurred

37 This view is based on my analysis of a number of salsilah of sayid families that I have collected. The significance of their being sayidsalsilah is that Nabi Mohammed is a well documented historical figure, whose life an be precisely dated.

Tom Harrisson, The Malays of Southwest Sarawak. p. 123.

Ibid.

40 Hugh Low, 'Selesilah (Book of the Descent) of the Rajas of Bruni', Journal of the Straits Branch of the Royal Asiatic Society, Vol. 5 (June 1880), pp. 1-35 at p. 2. MS B of the Selsilah published by Amin Sweeney omits Sadong from the list of negris transferred, and includes, instead, the Melanau negri of Mukah. P. L. Amin Sweeney, "Silsilah Raja-Raja Berunai", Journal of the Malayan Branch of the Royal Asiatic Society, 41:2, 1968. pp. 1-81 at p. 7. The inclusion of Mukah is likely to be an error, however. Melanau oral histories collected by A. E. Lawrence recall that the Melanau countries were conquered by the forces of the first ruler of Brunei, Alak Betatar, even before Brunei had embraced Islam. See A. E. Lawrence, "Stories of the First Brunei Conquests on the Sarawak Coast", Sarawak Museum Journal, II, 1911. pp. 120-124. 
prior to the end of the $15^{\text {th }}$ century,well before the Portuguese conquest of Melaka caused the Melakan ruling family to re-establish itself in Johor.It is, of course, possible that the identification of Johor in both the Merpati stories and the Brunei Selsilah could be later corruptions of earlier narratives, which might have referred, originally, to Melaka, which was founded and rose to regional dominance precisely during the period under consideration, 1410 to 1490.

But this possibility also raises problems. The SejarahMelayu, which chronicles the history of Melaka in detail, and which describes carefully the countries and kingdoms that accepted its suzerainty, makes no claim of Melaka's extending its dominionover any parts of Borneo. It makes no mention of the negris of Sarawak, Samarahan, Sadong, Saribas orKalakka. Nor does it mention, among its many descriptions of royal marriages, a union between a Melakan princess and anyone who could be interpreted as being DatuMerpati. Furthermore, no mention is made of a marriage between a ruler of Brunei and a Melakan princess, nor of the Melakan ruler's converting a Brunei ruler to Islam and endowing him with royal regalia.In contrast, however, the Raja of Kedah, for example, is described both as converting to Islam and as being invested by the ruler of Melaka with a drum of sovereignty for his regalia. ${ }^{41}$

These lacunae are made more important by the fact that the very purpose of the SejarahMelayu was to testify to the glory of Melaka and its dynasty, precisely by reference to the countries over which it held sway, the dynastiesthatsought its daughters in marriage and the rulers it converted to Islam. Norare any of these eventsmentioned byTomé Pires, who assiduously collected historical traditions from among the Melakans during the years following the Portuguese conquest, and whose book, the Suma Oriental, remains an invaluable source for Melaka's history. ${ }^{42}$

It is possible also, of course, that the references to Johor in both the Merpati stories and the Brunei Selsilah are fictions, interpolated into older narratives in order

41 "Sejarah Melayu or Malay Annals", translated by C. C. Brown, Journal of the Malayan Branch of the Royal Asiatic Society, XXV (2-3) October 1952. p. 137.

42 Suma Oriental of Tomé Pires: An Account of the East from the Red Sea to Japan, written in Malacca and India in 1512-1515. (translated and edited by Armando Cortesao), Hakluyt Society, second series, No LXXXIX, 1967. 
to imbue them, and the people they describe, with some of the status and glory of one of the major maritime powers in the Malay world and, of no less importance, withdescent from Melaka/Johor'sIskanderDzulkainan-descended dynasty.

There is, however, another controversial possibility to consider. Three elderly Abangs in Kuching, all well-versed in Sarawak Malay oral history, and one of them the acknowledged expert in the genealogies of the Kuching abang-abang, have all insisted in conversation with me that, when Johor is mentioned in oral histories, it denotes the kingdomof Sambas in west Kalimantan! ${ }^{43}$ There is one immediate difficulty, to which I have no resolution, with this suggestion - both the Merpati stories and the Brunei Selsilah refer to bothSambas and Johor. None of my informants had an answer to this problem when I asked them about it. They simply reiterated, emphatically, that, in the narratives, the term, Johor,refers to Sambas.

The identification of Sambas with Johor could have resulted from the fact that Dutch officials at the court of Johor in the early $17^{\text {th }}$ century believed that Sambas was a dependency of Raja Bongsu, the younger brother the Johor sultan. ${ }^{44}$ The leader of the pro-Dutch faction at the Johor court, Raja Bongsu attended "to many facets of political business, and especially issues relating to external alliances and foreign affairs", 45 including the conclusion in May 1606 of a formal alliance between Johor and the VOC. ${ }^{46}$ Raja Bongsu, himself, waslikely to have been the source of the Dutch officials' information about Sambas. In this scenario, Sambas could easily have been viewed, by Borneo peoples, as a Borneo extension of Johor.

Although it is likely that Raja Bongsu maintained an establishment at Sambas to trade for diamonds, manyimportant factorssuggest, however, that Raja

Bongsu'sclaims of suzerainty were exaggerated. The author of the late $16^{\text {th }}$ century (c

43 All three have asked me to protect their anonymity.

44 Peter Borschberg(ed.), Journal, Memorials and Letters of Cornelis Matelieff de Jong: Security, Diplomacy and Commerce in $17^{\text {th }}$-century Southeast Asia, Singapore: NUS Press, 2015. p. 295.

45 Peter Borschberg, "'Left 'Holding the Bag': The Johor-VOC Alliance and the Twelve Years Truce (1606-1612)", in The Twelve Years Truce (1609): Peace, Truce, War and Law in the Low Countries at the Turn of the $17^{\text {th }}$ Century, ed. by Randall Lesaffer. Leiden: Brill Nijhoff, 2014. pp. 89-121 at p. 98.

Ibid. p. 96. 
1590) source, the Boxer Codex, for example, considered that Sambas was under the overlordship of the queen of Jaua (Java, Mataram) rather than Johor. ${ }^{47}$ The ruler of Sambas, the PengiranAdipati, was at that time Hindu, a situation that was very unlikely to have been tolerated by a Moslem overlord - all of Johor's other dependencies were Moslem. Thirdly, in 1609 the Dutch themselves negotiated a treaty directly with the PengiranAdipati of Sambas, without any reference to Raja Bongsu. ${ }^{48}$ Fourthly, the slaughter of the VOC's officials at Sambas by PengiranAdipati and his followers in 1610 suggests that PengiranAdipati was little constrained by Raja Bongsu or his pro-Dutch policies. ${ }^{49}$ That the Dutch did not recriminate against Rajah Bongsuover the actions of his purported client also suggests that they were aware of PengiranAdipati's capacity for autonomous action.

Significantly, Johor is not recorded as having any historical claims over Sambas in either the SejarahMelayu or the later SilsilahMelayudanBugis and Tufhat al-Nafis, both of which report the $18^{\text {th }}$ century adventures in west Borneo of Bugis princes from Riau. 50 The absence of any Johor claims over Sambas in the SejarahMelayu is particularly telling, since Peter Borschberg makes a convincing case for that text's compilation having been initiated by Raja Bongsu, himself. ${ }^{51}$

Relations between Johor and Sambas were extensive, and important to both parties. Along with Sukadana to its south, Sambas was the main source of Borneo diamonds, Dutch interest in which was sufficient for the VOC to maintain a diamantkenner (diamond specialist) at the Johor Court. ${ }^{52}$ Sambas traded diamonds with Johor, most probably in exchange for the silk thread that was needed to make the

47 John S. Carroll, "Berunai in the 'Boxer Codex' (with Commentary)", Journal of the Malaysian Branch of the Royal Asiatic Society', 55:2 (283), 1982. pp. 1-25 at p. 3.

48 For the full text of the treaty see Borschberg(ed.), Journal, Memorials and Letters. pp. 446-448.

49 Ooi Keat Gin (ed.), Southeast Asia: A Historial Encyclopedia from Ankor Wat to East Timor. Santa Barbara: ABC Clio, 2004. p. 1170.

50 Sejarah Melayu, op. cit.; Hans Overbeck, "Silsilah Melayu dan Bugis dan Sekalian Raja-raja-nya", Journal of the Malayan Branch of the Royal Asiatic Society, 4:3 (98), 1926. pp. 339-381; Raja Ali Haji, The Precious Gift (Tuhfat al-Nafis). (Translated by Virginia Matheson and Barbara Watson Andaya), Kuala Lumpur: Oxford University Press, 1982.

51 Peter Borschberg, “'Left 'Holding the Bag”, pp. 14-15 passim.

52 Ibid. p. 25. 
kainsongket for which Sambas was famed. Pre-colonial Malay trade, however, was not conceived of as instrumental, secular or equal. Malays conceived of trade as tribute, as an unequal exchange, which gave expression to ritual inequality and hierarchy. When Malays traded with each other, each partner tended to believe that the other was supplicating them through undertaking the transaction, and, further,each party believed that their participation was an indication of their own munificence and superiority. Each party believed that the other, in receiving the goods they offered, was the recipient of budi, or benevolence.

Zainal Kling described budi as providing an indigenous, ideological underpinning for the operations of patronage. A central Malay value, budi refers to kindness or benevolence. It establishes "a subtly conceived reciprocal relationship between the donor and the receiver", in which the receiver, conceived of as makan(eating) budi, assumes an "implicit obligation to return the kindness". ${ }^{5}$ The concept ofmakanbudi encompasses other important dimensions, however. The obligation implicit in the process of makanbudi cannot be redeemed completely. The recipient is, forever, the client of the donor. ${ }^{54}$

The ambiguities involved in trading relations between Malay rulers were increased by the factthat pre-colonial states in maritime southeast Asia were not conceived of as autonomous and equal in the international system. Rather, smaller rulers sought to associate with greater rulers, owing them deference and support, in return for sharing the lustre of their greater reputations. The resulting ambiguity allowed both Raja Bongsu and PengiranAdipati to interpret their relationship in ways which enhanced their perceptions of their own status. Thus, while Raja Bongsu represented himself to the Dutch as being the overlord of PengiranAdipati, PengiranAdipati, was more likely to have represented his relations with Johor as demonstrating his own superiority. Whatever the reason, according to my Sarawak Malay informants, the Sarawak Malaysdid not just identify Sambas with Johor, they identified Sambas as Johor.

53 Zainal Kling, The Saribas Malays of Sarawak (Their Social and Economic Organisation and System of Values), University of Hull: Ph. D., 1973. p. 175.

54 For an extensive discussion of the complexites of the meaning of budi see the entry in R. J. Wilkonson, A Malay-English Dictionary (Romanised). London: Macmillan, 1959. 
Notwithstanding the complications that arise from the fact that the Merpati stories and the Brunei Selsilahboth refer to Sambas and Johor, the narrative which emerges from this revisionist historyis worth considering: The grandson either of a being who descended either from Heaven or from the Rajah Jawa, DatuMerpati, took refuge in Sambas, which was a dependency of Majapahit, from whose Emperor, according to one recension, he was descended. ${ }^{55}$ There he married the daughter of the ruler of Sambas. He settled for a while near Pontianak, to the south of Sambas, before moving, first, toTanjongDatu, which marks the boundary between Sambas and Sarawak,and, subsequently, toSantubong. For four generations, DatuMerpati and his descendants operated as officials of the Majapahit Empire, a role signified by their use of the title pati/pateh. It is likely that the activities of the four patis/patehs were supervised by Sambas, whose ruling dynasty was descended from that of Majapahit, ${ }^{56}$ rather than directly by Majapahit, itself.

At some point during the collapse of Majapahit by the end of the 15th century, Sambasboth asserted its own independence and took an independent control of the fivenegris to its northeast -Sarawak, Samarahan, Sadong, Saribas andKalakka. This assertion of power over the five negrisby Sambaswas probably facilitated both by the fact that the Sambas dynasty wasdescended from the rulers of Majapahit, and by the liklihood thatSambas had previously supervised the administration of the five negrison behalf of its Majapahit overlord.

The process of Majapahit'sexclusion by Sambas was,almost certainly, protracted and ambiguous. This would explain why the SalsilahAbangKipali describes DatuMerpati's grandson, PatehMengada as also being the first "Malay Patinggi". ${ }^{57}$ Unsure about the changing, relative power of Majapahit and Sambas, it is likely that Mengada used both the Majapahitpati/pateh and the Malaylanguage,patinggi titles. Of interest here, also, it the fact that, in Malay,mengada means to concoct an excuse or to pretend. It was only after the death of Mengada'sson,Pateh Malang, that Majapahit'spower wasreplaced, unambiguously, by

55 Theodore G. Th. Pigeau, op. cit., vol. III, pp. 16-17.

56 Christopher Buyers:The Royal Ark - Royal and Ruling Houses of Africa, Asia, Oceania and the Americas. www.4dw.net/royalark/Indonesia/Sambas2.htm. Accessed 24 April 2012.

57 Tom Harrisson, The Malays of Southwest Sarawak. p. 123. 
that of Sambas, rendering the continued use of the pati/patehtitle by the 'Merpatifamily'superfluous.

When the first Sultan of Brunei married the daughter of the Sambas ruler, the latter transferred sovereignty over the fivenegrisof Sarawak,Samarahan, Sadong, Saribas and Kalakkato his new son-in-law. These revised narratives have a coherence and force lacking in the originals, but they are, of course, impossible to prove.

\section{Brunei Rule}

The next written mention of Sarawak, after the Negara-Kertagama, is a Spanish report dating from 1530, which confirmsthat, whatever it previous relationship with Sambas, Sarawak was ruled as part of Brunei. It describes "Cerava” (Sarawak) as one of the four chief ports of Borneo (Brunei), inhabited by "many and rich merchants" whose trade consisted of diamonds, camphor, aloes-wood, provisions and wine. 58

Bob Reece suggested that the Sultan of Brunei gave Sarawak to a Portuguese captain, "penguilanMaraxa de Raxa" in 1578, in reward for 'de Raxa's' support against the Spanish. "Helping to restore Sultan SaifulRijal to the throne, it seems likely that de Raxa was rewarded with a wife and the opportunity to carve out his own little kingdom on the northwest coast."59

As I have already observed elsewhere, ${ }^{60}$ the main problem with Reece's reconstruction is the complete absence of any evidence to support it. Robert Nicholl explained, in a footnote to the documents to which Reece referred, that the phrase, "penguilanMaraxa de Raxa," was a Spanish rendering of a Malay title, Pengiran Maharaja de Raja. ${ }^{61}$ There is no mention in the sources of his being married to anyone, and it is not certain that he even went to Sarawak. He isreported to have been

58 Robert Nicholl (ed.), European Sources for the History of the Sultanate of Brunei in the Sixteenth Century. Bandar Seri Begawan, 1990 [1975]). p. 28.

59 Bob Reece, Datu Bandar Abang Hj. Mustapha of Sarawak. (Kuching, nd [1993?]) p. 4.

60 J. H. Walker, Power and Prowess: The Origins of Brooke Kingship in Sarawak. Crows Nest, NSW: Allen and Unwin, 2002. pp. 5-6.

61 Robert Nicholl, European Sources,p. 63. See also the Boxer Codex, in which the ruler of Brunei is called the raxa (raja). John S. Carroll, op. cit., p. 3. 
instructed by the Sultan to visit all the rivers "as far as Saragua". ${ }^{62}$

In fact, Reece seems to have confused the documents that he citedwith a narrative in the Selsilah Raja-Raja Brunei, in which the Sultan is described as extending his protection to a ship-wrecked Portuguese ship's captain. The Sultan "called the Captain his son and, and gave him the title PangeranKestani ... and made him a present of Manila, because it was after the Spaniards had attacked Bruni”. Although the captain promised to retake Manila from the Spaniards for the Sultan, a ship came and took him back to Macau. When the Captain later returned to Brunei to meet the Sultan, he had already died. ${ }^{63}$

\section{Revolt}

In 1609, only 20 years after the report in the Boxer Codex confirmed that Sarawak was ruledby Brunei, Valentynreported: "News received that the tribes north of Sambas, living in Calca [Kalakka], Saribas and Melanoege [Melanau] had defected from the king of Borneo and united themselves with the King of Djohor". ${ }^{64}$ In the same year, the Queen of Sukadana murdered her husband and abrogated his power to herself. ${ }^{65}$ Although it is unclear whether the Queen's regicide was related to the great revolt, it is worth observing Sambas entertained long-standing ambitions in Sukadana, which was its main rival in the diamond trade. The repudiation of Brunei rule by the Melanau areas must have been particularly galling to Brunei if, as Lawrence recorded, the Melanau areas were the first territories beyond Brunei Bay to have been incorporated into the kingdom, before even Brunei had embraced Islam. ${ }^{66}$

In view of the insistence of my informantsin Kuching that references to Johor are actually references to Sambas, we face the possibility that the 1609 revoltextendedSambas'spower as far north as the Melanauregionslocated to the north of the Rejang River. In extending its power up the coast, Sambasreasserted its authority over Sarawak, Sadong, Lingga and Kalakka, areas with which it had been

62 Robert Nicholl, European Sources,p. 63.

63 Hugh Low, op. cit., pp. 22-23.

64 S. A. Dovey, "Valentjn's Borneo," Brunei Museum Journal, IV(1978). p. 85.

65 Borschberg(ed.), Journal, Memorials and Letters. p. 580.

66 See A. E. Lawrence, op. cit., pp. 120-124. 
associated since the time of Majapahit, and which it had previously ceded to Brunei. This possibility draws support from the genealogical evidence assembled by Ann Appleton. Appleton found that some Pengiran families among the Melanau traced their descent to the Sambas ruling family,rather than directly to that of Brunei, ${ }^{67} \mathrm{a}$ point to which I shall return, and one whichsuggests Sambascontrolas far north as the Melanau regions at some point in time.

Although Baring-Gould and Bampfyldewere not prepared to attribute sovereignty over the Sarawak Malays (or the negristo their northwest) to Sambas, they confirmed that, although,

these settlements must have early succumbed to the rising power of Bruni....it is also evident that after that power had commenced to wane, its hold over Sarawak gradually weakened until it became merely nominal. In 1609, the year they established themselves at Sambas, the Dutch found that these districts had fallen away from Bruni...68

Conceding that there might "have been, and probably were, spasmodic assertions of authority on the part of Bruni", Baring-Gould and Bampfyldecontended, also, "it seems fairly evident that the Sarawak Malays managed to maintain an independence more or less complete for many years". 69

This last assertion, that the Sarawak Malays "managed to maintain an independence more or less complete for many years", is made so evidently in support of Brooke interests and claims that it should easily be rejected. The recorded use by successive generations of theabang-abang of Datutitles, such as Patinggi, Bandar and Tumonggong, necessarily required their holders to have received those titles from rulers whoseauthority they acknowledged. ${ }^{70}$ The important question to be considered is whether those rulers were the Sultans of Johor/Sambas or of Brunei.

\section{Sambas and Brunei: Contesting Sarawak}

67 Ann Appleton, "Pelajau Kaul and Sambas connection". Paper for the Conference Warisan Dan Sumber: Pergertian Sejarah, Budaya Dan Alam Borneo-Kalimantan", Universitas Palangka Raya, Palangkaraya, Kalimantan Tengah, May 2011.

68 S. Baring-Gould and C. A. Bampfylde, op. cit. p. 46.

69 Ibid.

70 Mohd. Yusuf Shibli, op. cit., p. 264. 
Ib Larsen's exploration of Sarawak's relations with Sambasfocussed,in particular, on narratives about Raja Tengah, his son and grandson. ${ }^{71}$ Rajah Tengah was the younger son of Sultan Hassan of Brunei. On the death of their father, his older brother, the new Sultan, nervous about Raja Tengah's ambitions, appointed him to be Sultan of Sarawak in 1599.Sultan Tengah established his capital at Santubong, building a fort and a palace and appointing

his senior officials. Among them was DatuPetinggi Seri Setia, DatuShahbandarInderaWangsa, Datu Amar SetiaDiraja and DatuTemenggong Laila Wangsa. ${ }^{72}$

Sultan Tengah then decided to visit his aunt, who was married to the Sultan of Johor/Sambas. ${ }^{73}$ While attempting to return to Sarawak, Sultan Tengah was blown off-course to Sukadana, south of Sambas. Sultan Tengah married the Sultan of Sukadana's sister, with whom he had five children, including his eldest son, Raden Suleiman. From Sukadana, Sultan Tengah and his family returned north to Sambas, where he married his son, Raden Suleiman, to the daughter of the Hindu ruler of Sambas, RatuSepudak, the PengiranAdipati of Dutch account. Leaving Raden Suleiman at Sambas, Sultan Tengah and his familyembarked on further travels, returning to Matan, to the south of Sukadana, for a period. ${ }^{74}$

At Sambas, after a range of conflicts with RatuSepudak's other son-in-law and successor, RatuAnum, Raden Suleiman becameSambas's first Moslem ruler in 1631. ${ }^{75}$ In 1641, Sultan Tengah and his family returned to Sarawak, whereSultan Tengah was, on his arrival, assassinated. ${ }^{76}$

Ib Larsen, op. cit., pp. 1-16.

72 Hugh Low, op. cit., p. 19; Rozan Yunos, "Sultan of Brunei Series - Sultan Tengah of Sarawak", The Daily Brunei Resources, http://bruneiresources.blogspot.com.au/search?q=Raja+Tengah. Date accessed 24 November 2015.

73 The is no evidence in the Sejarah Melayu of any Melakan/Johor ruler marrying a Brunei princess. Sejarah Melayu, op. cit. Ib Larsen (pers. comm., 17 December 2015), however, has drawn my attention to a reference in the Pahang salsilah of a contemporary ruler of Pahang being married to Sultan Tengah's aunt, Raja Bonda. See Christopher Buyers:The Royal Ark - Royal and Ruling Houses of Africa, Asia, Oceania and the Americas,http://www.royalark.net/Malaysia/pahang2.htm.

74 Ib Larsen, op. cit., p. 12.

75 E. U. Kratz, "Salsilah Raja-Raja Sambas as a Source of History", Archipel, 20, 1980. pp. 255-267pp. 259-260.

Ib Larson, op. cit., p. 5 
Although the historical sources from Brunei remainsilentabout how Sarawak was governed following Sultan Tengah's deathuntil about the mid- $18^{\text {th }}$ century (see below), as Larsen, observed, the essential question is whether Sultan Tengah was succeeded as Sultan of Sarawak by his son, RadenSuleiman who, on succeeding as ruler ofSambas in 1631, had taken theregnal title of Sultan Muhammad Tsaffiuddin. ${ }^{77}$

The Salsilah Raja-Raja Sambas records that Sultan Muhammad Tsaffiuddinsent his son, Raja Bima, to Brunei, where he was invested with nobat and the title, Sultan, before returning to Sambas, where he assumed power only after his father's death. ${ }^{78}$ In contrast, the Selsilah Raja-Raja Bruneiassertsthat Raja Bima was summoned to Brunei, where he was invested with sovereignty over Sambas. ${ }^{79}$ These contradictory accounts can be resolved if they are seen as describing two separate occasions. In the first account, Raja Bimatravelled to Brunei as his father's envoy, to do obeisance on his behalf for Sarawak, which would explain why Raja Bima did not assume power until after his father's death. On the second occasion, however, Raja Bima travelled to Brunei on his own account to be invested as Sultan.As Larsen noted, the Sultan of Brunei had neither any cause nor anyright to invest either Sultan Muhammad Tsaffiuddinor Raja Bima with Sambas. Their rights over Sambas derived not from Brunei, but from their descent from the previous rulers of Sambas who, in turn, derived from Majapahit. ${ }^{80}$

The only reason for either Sultan Muhammad Tsaffiuddinor Raja Bima to do obeisance at Brunei for the title, Sultan, was in connection with Sarawak or other areas which Sambas had detached from Brunei following the revolt of 1609. It seems likely, therefore, that references in the Selsilah Raja-Raja Brunei to the Brunei Sultan's investing Sultan Muhammad Tsaffiuddinand Raja Bima as Sultans of Sambas were designed to conceal the fact that they were invested as Sultans of Sarawak.

The narratives about Sultan Tengah in the salsilahs allow us to elaborate, also, on Valentyn's account of the revolt of 1609. Ambitious to succeed as Sultan of Brunei in place of his brother, Raja Tengah was dispatched, as a precaution, to rule distant 
Sarawak in 1599. Only 10 years later, extensive parts of Brunei extending from Sarawaknorth to the Melanau areas north of the Rejang, threw off Brunei rule and attached themselves to Johor/Sambas, with whose ruling house Sultan Tengah was later to forge a marriage alliance. It is difficult not to see Sultan Tengah's ambitious hand in orchestrating this great revolt.If Sultan Tengah was implicated in it, as seems likely, it would be hard not to consider his assassination in 1641, as part of an attempt by Brunei to re-assert its control. The oral history of an effigy of a crocodile, or Buaya Tanah, in KampungLebor near Serian, on the Sadong River to Sarawak's immediate north, recalls that it was constructed precisely in 1641 to commemorate the establishment of peace between the people of KampungLebor and Brunei. ${ }^{81}$ This necessarily suggests Brunei attempts to re-establish its power in the region at the time of Sultan Tengah's murder.

\section{Brunei resurgent}

Although the course of Brunei's struggle to regain control of the territories between TanjongDatu and the Melanau areas has not been recorded,it appears that it was still in the process of doing so during the reign of Sultan Muaddin. According to the Selsilah Raja-Raja Brunei, Sultan Muaddin, whose reign Nicholl dated to 16481670,82 “went to Kalekkato put in order all his provinces". 83 The Selsilah further records,

The son of His Majesty who was at Sambas at the time when Sultan Muaddin went to Kalekka was summoned to meet him there by His Majesty, who brought him back with him to Bruni. In Bruni he was invested as Sultan Anum ... After a time he was sent back to Sambas to govern it. ${ }^{84}$

Given that Rajah Suleiman had succeeded to the rulership of Sambas in 1631, and to the rulership of Sarawak in 1641, this entry seems to refer to one of his sons. The important point to note, however, is that the prince from Sambas was summoned to Kalakka precisely at the time that the Sultan of Brunei was attempting "to put in order all of his provinces". 85 These episodes in the BruneiSelsilah appear, therefore,

81 Hans van der Bunte, pers. comm., 28 May 2016.

82 Robert Nicholl, "Some Problems of Brunei Chronology", p. 193.

83 Hugh Low, op. cit., p. 18 (emphasis added).

84 Ibid., p. 21.

85 Ibid. 
to refer to an attempt by Sultan Muaddin to reassert Brunei control over parts of the coast between Sambas and Brunei. The fact that, in acting to "put in order all of his provinces", Sultan Muaddin had cause to summon a Sambas prince suggests, further, that the re-establishment of Brunei order required negotiations with Sambas.

Ann Appleton's research, referred to above, has established that the MelanauPengirans of Oya trace their descent to RadenBima's younger brother, RadenRatnaDewi. ${ }^{86}$ It is possible, therefore, that the prince summoned to Kalakka by Sultan Muaddin was RadenRatnaDewi, who might already have established himself in the Melanau area, and who Sultan Muaddin might have sought to convert to his own cause by granting him the title, Sultan Anum. ${ }^{87}$ Whatever the case, as Larsen observed of Appleton's findings, "The story indicates that during the generations after Raden Suleiman the Sambas royal family expanded their territory even further up the coast from Sarawak". 88

More importantly, the fact that there is such strong genealogical evidence that Sambas extended its control over the very areas which Valentyn reported had acclaimed the ruler of Johor, and that it had done so during the period immediately following that acclamation, is powerful evidence in support also of identifying the Johor of these narratives with Sambas, as claimed by my informants in Kuching. It was not just, therefore, Sultan Muhammad Tsaffiuddin's and Raja Bima's rule over Sarawak Proper that the Selsilah Raja-Raja Brunei needed to conceal. It needed to camouflage also that Brunei's rulers had lost control of vast swathes of the northwest coast to their Sambas kinsmen.

In 1911, E. Parnell published an account of "an account of the various tributes received by the Sultan of Brunei from his feudatory chiefs in charge of the provinces, now known as Sarawak". ${ }^{89}$ Parnell noted that the document was written by "DatuEmaumYakob", who served as Datu Imam during the reigns of Sultans

\footnotetext{
86 Ann Appleton, op. cit.
}

87 In contrast, MS. B of the Silsilah Raja-Raja Berunai published by Sweeney records that it was Pengeran Mangkunegara, Raja Tengah's son from his other marriage with a princess from Matan, who was entitled Sultan Anum. P. L. Amin Sweeney, op. cit., pp. 23-29.

88 Ib Larsen, op. cit., p. 13.

89 E. Parnell, "The Tributes Paid in Former Days to the Sultan of Brunei by the Dependent Provinces of Sarawak", Sarawak Museum Journal, 1, 1911. pp. 125-130. 
Muaddin and Kamaluddin of Brunei, and that it was about 180 years old. ${ }^{90}$ This would date it to about 1730, firmly in the reign of Sultan Kamaluddin.

That Sultan Kamaluddinsought to establish the tribute due from, and the terms of the administration of,theprovinces of Brunei, most of which had previously been ruled by Sambas suggests, precisely, that Brunei had only recently regained control of them. It seems likely, therefore, that Brunei regained control of the areas which now comprise greater Sarawak by about 1730 .

According to Datu Imam Ya'akub, the countries from Sarawak Proper to Brunei were divided into three administrative units. Territory from Brunei to Blahit was the joint responsibility of the Pengiran di Gedong and the Orang Kaya di Gedong. Territory from Miri to Baraya was under the PengiranBendhara, while the lands from Mukah to Sarawak Proper were the responsibility of the Orang Kaya di Gedong. ${ }^{91}$ These divisions of responsibility might relate to the nature of the ownership or tenure of each territory. Donald Brown noted that Brunei's provinceswere divided in three types of territorial administration: kerajaan, which comprised the appanages of the sultan, kuripan, which were allocated to officials for their maintenance, and tulin, which were held families by hereditary right. Sarawak was a kerajaan..$^{92}$

Datu Imam Ya'akub set out a complex system of annual and special tributes. ${ }^{93}$ The negristhat he mentioned by namewereKalakka, Saribas, Sebangan (north of the Brunei capital), Sadong, Sarawak, Sebuyau, BatangLupar, Melanau and Skrang. ${ }^{94}$ The provincial officials whom he listed as owing tribute were the DatuPatinggi and Orang Kaya Bandar of Kalakka; the DatuPatinggi and Datu Bandar of Saribas and the Mentris of Saribas, Kalakka, Sebangan, Melanau and

\footnotetext{
$90 \quad$ Ibid., p. 126.

91 Ibid., p. 130.

92 D. E. Brown, Brunei: The Structure and History of a Bornean Malay Sultanate. Brunei: Monograph of the Brunei Museum Journal, 1970. pp. 79-85.

93 E. Parnell, op. cit., p. 127.

94 Ibid., pp. 127-128.
} 
Sadong. The position of Shahbandar is listed, but without any particular territorial designation. The dayangdayang and anakMentri are also listed as liable for tribute. 95

It is interesting that, although Sarawak is mentioned as owing tribute, no Datusor Mentrisare listed in association with it.The document that Parnell described had either been copied from or was later interpolated into MSA of the Selsilah RajaRaja Berunaipublished by Sweeney. ${ }^{96}$ In contrast to Parnell's version, Sweeney'sdoes make mention of a 'MenteriSerawak'. ${ }^{97}$ That Sarawak was governed by a Mentri(minister) raises the question of whether the Brunei ruler entertained doubts about the extent to which the abang-abang of the Sarawak River could be relied upon to resist the rival claims of the more proximate Sambas court, with whom they had for so long been associated.

It seems likely that the document described by Parnell had been copied from MS A of the Selsilah, and sent to the various provincial administrations to informtheir elites of their tribute obligations. The sources of Datu Imam Ya'akub's information were said to have been Sultan Muhiuddin (Low's Sultan Muaddin), Sultan Kamaluddin and the DatuPerdanaMenteri. 98 That the DatuIman had to source his information from two Sultans, again, suggests that the Brunei was reinstituting a system of tribute rather than recording an existing system.

\section{Back and Forth ...}

Graham Irwin cited Dutch sources to argue that, in the early nineteenth century, Brunei governed Sarawak through two Brunei pengirans who controlled the export of jungle produce on behalf of the Brunei elite. ${ }^{99}$ Although I have previously accepted Irwin's position, ${ }^{100}$ it should have been clearer to me that it appears that, notwithstanding Brunei's success in retaking control of the northwest coast by about 1730 , by the late $18^{\text {th }}$ or early $19^{\text {th }}$ century, Sambas seems have succeeded, again, in supplanting Brunei's power. It might even have been the success of Sambas's renewed ambitions which led Datu Patinggi Abdul Gapur's paternal grandfather, Bilal

\footnotetext{
95 Ibid., pp. 128-129.

96 P. L. Amin Sweeney, op. cit., pp. 25-29.

97 Ibid., p. 25. MS A had, earlier in the text, referred to the Tumanggong, Bandar and Patinggi of Sarawak. See p. 16.

98 Ibid., p. 2.

99 Graham Irwin, op. cit., p. 73.

100 J. H. Walker, op. cit., p. 24.
} 
Abdul Latif, who originated from Brunei, ${ }^{101}$ to settle in Sarawak during this period. The title, bilal, denotes (religious) leadership. I should have considered, therefore, whether Abdul Latif 's relocation to Sarawak from Brunei represented an attempt to re-extend or increase Brunei influence among the Sarawak Malays at a time when controll of the area was again being contestedby Sambas.

In 1811, Burns reported to Rafflesthat the ship, Commerce, had been destroyed near Santubong by "Pangeran Samewda of Sarawak, a relative of the sultan of Sambas". ${ }^{102}$ Raffles, himself, later wrote to Lord Minto, complaining about the pirates of "Serawa", who, he noted, had operated in conjunction with those of Sambas to disable the ship. ${ }^{103}$ As Larsen observed, that the British retaliated for the destruction of the Commerceby bombarding Sambas, rather than by attacking Sarawak,demonstrates strongly that they considered 'Pengiran Samewda' to be a dependent of, and responsible to, the Sultan of Sambas. ${ }^{104}$ After their bombardment of Sambas, the British commander sent a letter to a 'Raja of Sarawak', presumably the same 'Pengiran Samewda', admonishing him for his piracy. ${ }^{105}$ The fact that, several years later, in 1819, the Sultanof Sambas was reported as being on the Sambas/Sarawak border, also suggests that he had interests in Sarawak. ${ }^{106}$

Around 1823, commercial deposits of antimony were discovered in Sarawak. ${ }^{107}$ The valuable potential of the antimony deposits seems to have galvinised the Brunei Court into action. Determined to secure control of them for Brunei, Sultan Omar Ali of Brunei dispatched to Sarawak the Pengiran Indera Mahkota, whosucceeded in reestablishing Brunei control over Sarawak for a short period, and who sought to establish a Bruneian monopoly over the antimony. ${ }^{108}$ Sambas appears to have

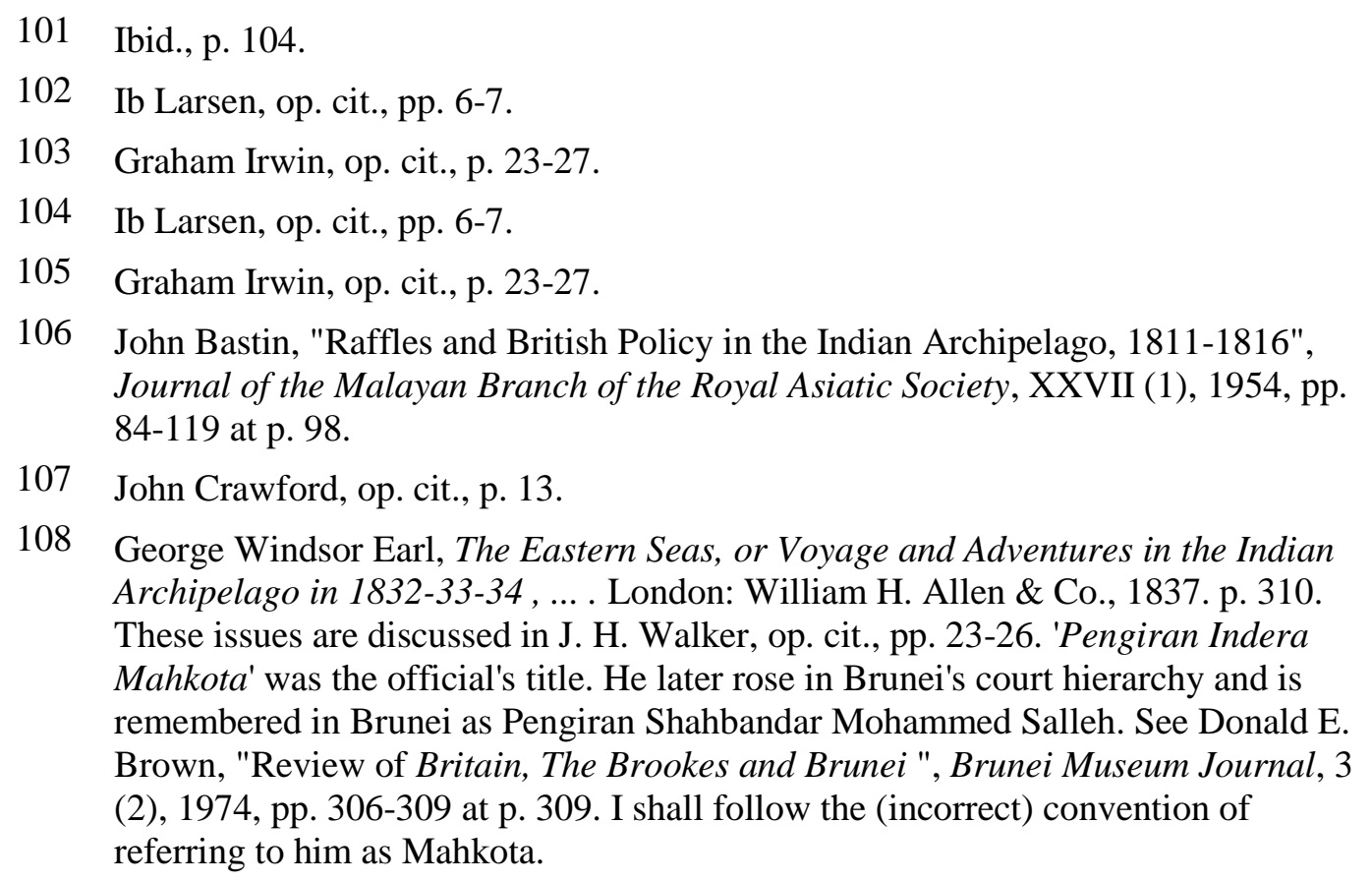


successfully contested Brunei's these attempts with Earl reporting, for example, Sambas nobles bringing two or three brigs loaded with antimony to Singapore. ${ }^{109}$

Sultan Omar Ali's choice of Mahkota to establish his authority in Sarawak is telling. Mahkota had extensive, intimate family ties with the Sambas royal family. His father, a member of the Brunei ruling family,had settled at Sambas and married a daughter of its Sultan. Mahkota was, therefore, a maternal grandson of Sultan Umar Akamuddin IIof Sambas and was, additionally, married to "a lady from the Sambas Royal family". Further, both his sister and uncle had married Sambas royalty. ${ }^{110}$ These extensive family connections presented Makhota with two important advantages in Sarawak. First, they probably inhibited significantly the Sambas Court's reaction to his presence. Secondly, he is likely to have tried to use his connections with Sambas to mollify those Sarawak Malayswho remained loyal to the Sambas Court. His ancestory comprised, effectively, a genealogical compromise between Sambas and Brunei.

Notwithstanding these family connections, Makhota's intrusion into Sarawak was unlikely to have pleased either the Sambas Court, its Dutch allies or the Sambas Court's Sarawak Malay collaborators. In 1831, eight years after Makhota had arrived in Sarawak, the Dutch Resident at Sambas proposed to the Netherlands Indies Government that the Sultan of Sambas should acquire from Brunei the areas of Lundu, Sematan, Sarawak and Sadoud (Sadong?). The Sambas Sultan sent an emissary to Brunei to negotiate the transfer. ${ }^{111}$ Although we have few details about the mission, at least part of the Brunei Government appears to have favoured the proposal. One of Sultan Omar Ali's uncles, Pengiran Usop, went to Sarawak in about 1835 and agreed "for a sum of money" to transfer the province to the Sultan of Sambas's brother. Following the refusal of Sultan Omar Ali's most senior uncle, and heir-presumptive, Raja Muda Hassim, to agree to the proposal, Usop provoked the Sarawak Malays to revolt in 1836. ${ }^{112}$ In view of the Sarawak Malays' long association with Sambas, theyare unlikely to have needed much encouragement.

109 George Windsor Earl, op. cit., p. 310.

110 Christopher Buyers, "Brunei", The Royal Ark - Royal and Ruling Houses of Africa, Asia, Oceania and the Americas.. http://www.royalark.net/Brunei/brunei6.htm, p. 6. Accessed 24 November, 2015.

111 Graham Irwin, op. cit., p. 69.

112 Henry Keppel, The Expedition to Borneo of HMS Dido for the suppression of Piracy: with extracts from the journal of James Brooke, Esq. of Sarawak, (now agent for the British Government in Borneo); (London, 1846 [second edition]), I, p. 208. (To distinguish between the two principal journals published herewith Brooke's will be cited as 'Brooke, Dido,' and Keppel's as 'Keppel, Dido'.) J. Brooke to J. C. Templer, 25 September 1841. Templer, J. C., (ed.) The Private Letters of Sir James Brooke, K. C. B. 
Thetraditional leadership of the Sarawak Malays was was divided among the Datu Patinggi, the most senior of the datus, who ruled the right hand branch of the Sarawak river, the Datu Bandar who governed the left hand branch, and the Datu Tumanggong who governed the coastal areas and adjacent islands. ${ }^{113}$

As I have demonstrated elsewhere, however, by 1840, the Sarawak Malay leadership was more fragmented than this outline suggests, with the Patinggi title contested between Datu Patinggi Ali and his son-in-law, Datu Patinggi Abdul Gapur. ${ }^{114}$ The Sarawak Malays lived principally at Leda Tanah, Datu Patinggi Ali's seat, and at a place called Katupong, ${ }^{115}$ which might have been Datu Patinggi Abdul Gapur's residence. Both sites were upriver from present day Kuching.

It is not clear from the sources how two Patinggis came to be appointed. It is possible that they both were appointed either by the Sultan of Brunei or by the Sultan of Sambas, or that both Sultan had each appointed a contender. In the first scenario, possibly, unhappy with the performace of the first appointee, the Sultan (whichever it was) appointed the second in the hope his being more compliant with the Ruler's wishes. In the second scenario, each Sultan appointed his own patinggi to project his power into the area.

Spenser St. John wrote that the Sarawak rebels received arms and ammunition from the Sambas Court, ${ }^{116}$ and it is likely that the Sultan of Sambas provided the rebels with the three six-pounder cannon that they were later reported to have. ${ }^{117}$ Notwithstanding Sambas's support, by 1839 the conflict hadstalled. The insurgents controlled upriver areas. Brunei controlled downriver from somewhere between Siniawan and Kuching, the Lundu River, and the lower Samarahan

Rajah of Sarawak. London: Richard Bentley, 1853 (hereafter cited as Letters), I, p. 114. Emily Hahn reproduced part of a report to the Dutch Government by the Dutch Indies Deputy Governor-General, Merkus, which confirms Usop's role in raising the rebellion. See Emily Hahn, James Brooke of Sarawak: A Biography of Sir James Brooke. London: Arthur Barker, 1953. pp. 66-67.

113 Brooke, Dido, I, p. 270. By left hand branch, European observers meant the eastern branch. The western branch was referred to as the right hand branch. See "Diary of Hugh Low, 1844-1846", John Pope-Henessey Papers, Box 5/1/1, f. 52 (Typescript).

114 J. H. Walker, op. cit., p. 24.

115 S. Baring-Gould and C. A. Bampfylde, op. cit. p. 64.

116 Spenser St. John, Rajah Brooke: The Englishman as Ruler of an Eastern State. (London, 1897) p. 28.

117 Brooke, Dido, I, pp. 154-156. 
River. ${ }^{118}$ In 1839, in an attempt to break the stalemate, the rebels sent messages to the Dutch Assistant Resident in Sambas offering, in return for increased support, to cede their country to the Netherlands. At the same time they sent a delegation to Batavia to lobby the East Indies Government, itself. ${ }^{119}$

\section{James Brooke's Intrusion}

In August 1839, an Englishman, engaged on a voyage of geographical enquiry, arrived in Sarawak. ${ }^{120}$ His name was James Brooke. Brooke's ship, Royalist, was armed with six six-pounder cannon, in addition to swivel guns and "small arms of all sorts". 121 The Brunei authorities at Sarawak immediately perceived that Brooke possessed additional resources that could be importantinresolving the conflict in their favour. Brooke, himself, recorded that he was flattered and shown consideration precisely because "the Rajah wishes me to stay here as a demonstration to intimidate the rebels". ${ }^{122}$

Uncertain of the likelihood of military success, and seeking to secure his interests in other ways, the Sultan of Sambas wrote to his cousin, Mahkota, offering to assist him in developing the antimony deposits and requesting permission to trade in Sarawak. Mahkota's unease over Sambas's intentions is demonstrated by his exploration in conversation with Brooke, of the possibility of Brunei's securing British support against the Dutch. ${ }^{123}$ Similarly, on the very first day of his acquaintence with Brooke, Rajah Muda Hassim, ${ }^{124}$ who Sultan Omar Ali had

118 See Brooke's letters to J. C. Templer of August 1839. Letters, I, pp. 66-68; and his diary entry for 23 August 1839, Brooke, Dido,I, p. 36.

119 See "Minutes of a Conversation between the Datu Bandar, the Datu Imaum, the Datu Tumanggong and the Tuan Khatib ... and Mr. St. John... ." Brooke Family Papers, Box 23, file 1, ff. 47-50 at f. 47.

120 Brooke, Dido, I, pp. 26-28.

121 Brooke, Dido, I, p. 8.

122 Brooke, Dido, I, pp. 29-30 (Original emphasis).

123 J. Brooke to J. C. Templer, 20 August 1839. Letters, I, p. 67. See also Rodney Mundy, Narrative of events in Borneo and Celebes, down to the Occupation of Labuan: From the Journals of James Brooke, Esq., Rajah of Sarawak, and Governor of Labuan. Together with a Narrative of the Operations of HMS Iris. (London, 1848) vol. 1, p. 376. (To distinguish between the two journals published herewith Brooke's will be cited as 'Brooke, Iris,' and Mundy's as Mundy, Iris.) I, p. 19.

124 For Hassim's role in Sarawak see J. H. Walker, op. cit., pp. 26-29. 
dispatched to Sarawak to deal with the insurgency,also questioned Brooke about the state of Anglo-Dutch relations. ${ }^{125}$

Brunei's forces achieved a vital strategic advantage over the rebels with their construction of a fort at a site called Sekundis, a position well-placed to interdict the Sambas resupplyline to the rebel position at Siniawan. ${ }^{126}$ On 20 December 1840,cut off from their resupply route to Sambas, the insurgents surrendered. ${ }^{127}$ Rajah Muda Hassim took the wives and children of the insurgency's leaders as hostages. ${ }^{128}$ Of the leaders themselves, Datu Patinggi Ali found refuge among the Malays at Sarikei, on the Rejang. ${ }^{129}$ Datu Patinggi Abdul Gapur and Datu Tumanggong Mersal withdrew to the protection of the Sultan of Sambas, with whose family their ancestors appear to have enjoyed deep and sustained relations across centuries.Datu Patinggi Abdul Gapur's withdrawal to Sambas suggests that his title derived from the ruler of Sambas rather than Brunei.

Brooke had earlier recorded that, when he had proposed to leave Sarawak, Rajah Muda Hassim had offered to transfer the governorship of Sarawak to him, if he would stay and help suppress the insurgency. Hassim "offered me the country of Siniawan and Sarawak, and its government and trade, if I would only stop and not desert him." 130 Following the surrender of the rebels, however, Brooke first "observed a slackness, then a slight shade of coolness, and then an evident wish to evade all discussion about the settlement of the country". Brooke was forced to the realisation that Hassim's offers were cancelled - "all previous calculation is defeated", he wrote. ${ }^{131}$ Relations soured, with Hassim withdrawing to his house, and refusing for three weeks even to see Brooke. ${ }^{132}$

Brooke's estrangement from Hassim provided the leaders of the insurgency with a means of securing their futures in theirown homeland without having to accept

125 Brooke, Dido, I, p. 31. In 1837 the Brunei Court had already epressed its concerns over Dutch ambitions to the officers of the Himmaleh. See "Notices of the City of Borneo and its Inhabitants, made during the voyage of the American brig Himmaleh in the Indian Archipelago, in 1837 - Part 1", Indian Repository. VII (3), pp. 121-136 at 132.

126 Brooke, Dido, I, p. 175-178; Brooke, Iris, I, p. 178.

127 For a detailed analysis of the circumstances of their surrender see J. H. Walker, op. cit., pp. 41-43.

128 Brooke, Dido, I, pp. 182-188.

129 Brooke, Dido, I, p. 254.

130 Brooke, Dido, I, pp. 170-171.

131 J. Brooke to J. C. Templer, 24 July 1841. Letters, I, p. 106.

132 Brooke, Iris, I, p. 248. 
Brunei rule. Datu Tumanggong Mersal and a son of Datu Patinggi Ali led a secret delegation to Brooke, "to request him to become their Rajah, offering to support him by force of arms". ${ }^{133}$ Needing to represent Brooke both as man of honour,and as a rulerwho had been installed by the legitimate authority of Brunei, Baring-Gould and Bampfylde claimed that Brooke refused their suggestion. ${ }^{134}$ Brooke, himself, however, seemed to concede the point. He confirmed at one time that the Sarawak Malays had "offered ... to support me, in obtaining the Government of the Country ... accepting the Government I offered, and resisting the Government of the native princes", ${ }^{135}$ and he explainedat another time that his position as Rajah emanated "from the will of a free people to choose its own form of Government and the Functionaries by whom it shall be administered". 136

Emboldened, therefore, by the secret support of the Sarawak Malays, on 23 September 1841 Brooke turned the guns of theRoyaliston to the town. Arming themselves, he and members of his crew landed and were joined by 200 well armed Sarawak Malays. In the face of such armed force, Hassim agreed to install Brooke as Rajah, ${ }^{137}$ which he did in public on the following day. Nothing, Brooke considered, "can be more flourishing than the present state of my affairs". ${ }^{138}$ Brooke's heady optimism was premature, however. The Sultan of Sambas, whose family had either ruled or sought to rule Sarawak at least since the time of Majapahit was not to be so easily precluded from achieving his centuries-old ambition.

In early 1841, the Sultan of Sambas had sent a brig, commanded by a "man of rank", to trade at Kuching. James Brooke considered the ship's arrival to be part of a plot. During the period of his estrangement from Hassim, Brooke recorded that intrigues "are at work which I cannot at present unravel". He believed that a group of Malay chiefs were trying to involve him in "a dispute with the Dutch authorities at Sambas". Confronting the chiefs, he "sent them from my presence, perplexed, ashamed, and trembling". 139

133 "Minutes of a Conversation between the Datu Bandar, the Datu Imaum, the Datu Tumanggong and the Tuan Khatib ... and Mr. St. John ... ." Brooke Family Papers, Box 23, file 1, ff. 47-50 at f. 48.

134 S. Baring-Gould and C. A. Bampfylde, op. cit., pp. 72-73.

135 Testimony of Sir James Brooke, FO 12/21/56.

136 J. Brooke to Addington, 13 March 1852, FO 12/11/72;

137 Brooke, Iris, I, pp. 270-271; Brooke, Dido, I, pp. 251-252.

138 J. Brooke to J. C. Templer, 28-29 September 1841. Letters, I, p. 118.

139 Brooke, Iris, I, pp. 239 and 252-253. 
Although the new Rajah of Sarawak claimed that Mahkota had allied himself with the Sultan of Sambas against him, ${ }^{140}$ this seems unlikely. Notwithstanding Makhota's kinship with the Sultan of Sambas, he demonstrated throughout his career an unshakable loyalty to the Sultans of Brunei, to one of whom he dedicated his autobiography. ${ }^{141}$ AsI have noted elsewhere, the chiefs who Brooke confronted were probably Sarawak Malays, and the plots he suspected probably related to differences within the Sarawak Malay leadership over whether to support Brooke's claims or those of the Sambas ruler. ${ }^{142}$

The Sultan of Sambas responded to Brooke's seizure of the Government of Sarawak by renewing his efforts. He dispatched two of his sons to Sarawak, claiming that unpaid debts gave him financial rights over any antimony mined by the Chinese miners. Brooke considered that the arrival of the Sambas rajas presaged "the greatest and I hope the final struggle of the opposing faction". Significantly, he was not sure whether the Sarawak Malays would support his claims against those of Sambas. ${ }^{143}$

Without giving or, probably, knowing any of the detailsabout the Sarawak Malays' history with and loyalty to the Court of Sambas, Brooke recorded that the Sambas party left Kuching on 30 December1841, "after exhausting every effort of intrigue, and every artifice which Malays can invent, to compass their ends."144

They could not have known it at the time, but the Sambas Malays' departure from Sarawakall but ended Sambas's involvement with the area, an involvement that had endured, despite the best efforts of successive Sultans of Brunei, for 500 years, or longer.Although Brooke's rapid consolidation (and expansion) of his rule in Sarawak precluded Sambas's again regaining control over it,members of the Sambas royal family continued to consider that they had rights over the area. As late as 1862, for example, Charles Grant apprehended a Sambas prince atttempting to raise revenues from Sematan, the region of Sarawak most proximate to Sambas. ${ }^{145}$

\section{Conclusion}

Sarawak appears to have been the site of an early Indianised state centred on Santubong, dating from the the sixth to the $13^{\text {th }}$ centuries, and known in the Chinese

140 Brooke, Dido, I, p. 245.

141 See his Syair Rakis. Brunei: Pusat Sejarah Brunei, 1983.

142 J. H. Walker, op. cit., p. 46.

143 Brooke, Dido, I, pp. 252 and 257.

144 Brooke, Dido, I, p. 261.

145 B. Brooke to J. Brooke, 21 August 1862. Basil Brooke Papers, vol. 5, f. 474. 
records as P'o-li and Po-ni, successively. It enjoyed strong trading or tribute relationships both with upriver and maritime tribeswhich were skilled in collecting forest and martime products which the state injected into the world economy, and sent, on successive occasions, to China as tribute. Such Chinese recognition must have been important in securing and maintaining the state's independence, first, from Srivijaya and, subsequently, from Majapahit. This state, rather than Majapahit, is likely to have been the earliest source of the Indianisation of cultures in Sarawak Proper.

Whereas Larsen dated Sambas's control of Sarawak to the accession of Rajah Suleiman in 1641, the analysis offered above suggests that Sambas had controlled area much earlier, during the final years of the Majapahit empire and beyond. Following the demise of Po-ni by the $14^{\text {th }}$ century, Sarawak became a tributory of Majapahit, on whose behalf Datu Merpati, his son, grandson and great-grandson, collected tribute. It is likely that the patis/patehs were supervised in their duties by their kinsmen, the rulers of Sambas, who were both descendents and dependents of the Majapahit ruling family. Indeed, the marriage of Datu Merpati to the daughter of the ruler of Sambas might well have been orchestrated to ensure Datu Merpati's loyalty to the rulers of Sambas.

Following the collapse of Majapahit by the end of the $15^{\text {th }}$ century, Sambas asserted its own, independent control over Sarawak, as well as over the neighbouring negris of Samarahan, Sadong, Saribas and Kalakka. When the first ruler of Brunei, Sultan Muhammed, ${ }^{146}$ married the ruler of Sambas's daughter, the latter endowed his new son-in-law with these five negris. Brunei ruled the areas from the time of Sultan Muhammed, c.1514, until 1609, when the northwest coast as far north as the Melanau areas threw off its allegiance to Brunei and acclaimed the rule of Sambas, with whom most of them had previously enjoyed a long association. Thereafter, Sarawak's history is one of continual and tedious contests between Sambas and Brunei.

On the basis of this analysis, it is possible to confirm Larsen's findings, to extend them and to establish a tentative periodisation of Sarawak's political history. Sambas exercised sovereignty from the late $14^{\text {th }}$ century until about 1515 , when control was transferred to Brunei. Brunei rule lasted until 1609, when the coast revolted and declared its loyalty to Sambas. Sambas managed to hold extensive tracts of the northwest coast from 1609 until about 1730, when Brunei successfully regained control, instituting the system of tribute recorded in MS A of the Selsilah Raja Raja Berunai. Brunei's success was not sustained, however, with Sambas again controlling

146 Sultan Muhammed's offical regnal dates in Brunei are 1363 to 1402. Nicholl, however, dated his conversion to 1514/1515. Robert Nicholl, op. cit., p. 192. 
Sarawak from the late $18^{\text {th }}$ century until the 1820 s. Following the discovery of antimony in 1823, Pengiran Makhota was successful in again regaining control of Sarawak for Brunei from 1826 until about 1835, when the Sarawak Malays rose in a revolt in support of Sambas's ambitions.

Thus, for 500 years Sambas had ruled or sought to rule Sarawak, determinedly and, often, successfully contesting Brunei's claims to the area. This long competition was ended only with the rise to power in Sarawak of James Brooke, who successfully excluded both Sambas and Brunei from the area.

Much of the coherence of this narrative derives entertaining the claim that references in Sarawak Malay and Brunei histories to Johor are references to Sambas.Although this contentious claim is difficult to prove, there is one important piece of evidence, noted above, in support of it - the fact that, shortly after the 1609 revolt, which saw areas north of Sambas acclaim the ruler of Johor, those areas were clearly ruled by Sambas.

The Brunei Selsilah conceals the claims of Sambas, which contest its own claims. Sultan Tengah's son and grandson both did obeisance at Brunei for the title of Sultan. Although successive scholars have interpreted this as indicating Brunei control over Sambas, as Larsen argued, it is much more likely to have indicated continued Sambas rule over Sarawak.

Salsilahs in the Malay world were composed and promolgated to extoll the powers and virtues of the rulers whose descent they recorded. In doing so, we should not be surprised that they conceal as well as record. Such attempts can be complex, sophistocated and enduring. O. W. Wolters revealed just such an attempt in the Sejarah Melayu, itself, which invented an extended period of rule over Singapore by the Palembang dynasty in order to conceal the fact that Palembang had lost power to its rival, Melayu. ${ }^{147}$ Scholars are entitled to wonder about the extent to which the Brunei Selsilah's references to Johor were designed to conceal the claims of Sambas. Similarly, claiming descent from a Johor princess rather than a Sambas one links the Brunei dynasty to the more Islamic Melaka-Johor family, with its purported descent from Iskander Zulkainan, in preference to the Hindu Majapahits.

It is possible, additionally, that references to Johor in the Datu Merpati stories are also designed to conceal both the enduring loyalties of the Sarawak Malays to the Court at Sambas, and Sambas's enduring claims over Sarawak. James Brookebecame, following his installation as Rajah of Sarawak, the focus of loyalty of the Sarawak

147 Wolters, O. W., The Fall of Srivijaya in Malay History. Kuala Lumpur: Oxford University Press, 1970. 
Malays, whose leaders wereimportant collaborators in the Government of the country. ${ }^{148}$ Brooke's legitimacy derived from Brunei's transferring its claims over Sarawak to him. In this context, it would have been important for those Sarawak Datus and abang-abang who were converted to Brooke's causeto deny and conceal the rival claims of Sambas, which could have been used to contest Brooke's position.

Two further issues arise, however, and await additional study. The principal problem with identifying Johor with Sambas is the fact that the Sarawak and Brunei narratives mention both places. This should not be seen as an insumountable obstacle until the narratives' uses of Sambas and Johor have been subjected to a closertextual analysis than is possible here.

But the Datu Merpati stories and the narratives about Sultan Tengah also raise another issue which awaits investigation - their parallel nature:Datu Merpati goes to Johor/Sambas, where he marries the ruler's daughter. His ship is blown by a storm to Sukadana, south of Sambas. Attempting to return to Johor/Sambas, he lands at Tanjong Datu, where he settles for a while, before moving to Santubong.Sultan Tengah also goes to Johor/Sambas. Returning to Sarawak, his ship also is blown of course to Sukadana, where he marries the ruler's daughter. Before moving to Sambas/Johor, and later to Matan, and, finally, returning to Santubong. The movements of the two men are summarised below:

Datu Merpati: Johor/Sambas-Sukadana-Tanjong Datu-Santubong Sultan Tengah: Johor/Sambas-Sukadana-Sambas/Johor-Matan-Santubong

Quite apart from the fact that both Datu Merpati and Sultan Tengah either were very unlucky with the weather, or they were terrible sailors, the parrallels in the narratives are striking.Both sets of narratives await further analysis to determine what these parrallels might reveal, or, indeed, what they might be concealing.

148 See J. H. Walker, op. cit., Chapter 3. 
